\title{
FORMATION OF BIOFILMS BY STAPHYLOCOCCUS AUREUS ON STAINLESS STEEL AND GLASS SURFACES AND ITS RESISTANCE TO SOME SELECTED CHEMICAL SANITIZERS
}

\author{
Simone Cristina Marques ${ }^{1 *}$; Jaíne das Graças Oliveira Silva Rezende ${ }^{1}$; Lizandra Aparecida de Freitas Alves ${ }^{1}$; \\ Belami Cássia Silva ${ }^{1}$; Eduardo Alves ${ }^{2}$; Luiz Ronaldo de Abreu ${ }^{1}$; Roberta Hilsdorf Piccoli ${ }^{1}$
}

${ }^{1}$ Departamento de Ciência dos Alimentos, Universidade Federal de Lavras, Lavras, MG, Brasil; ${ }^{2}$ Departamento de Fitopatologia, Universidade Federal de Lavras, Lavras, MG, Brasil

Submitted: June 19, 2006; Returned to authors for corrections: February 15, 2007; Approved: July 18, 2007.

\begin{abstract}
The objectives of this work were to verify the capability of Staphylococcus aureus of forming bio-film on stainless steel and glass surfaces; to evaluate the efficiency of sodium dichloroisocyanurate, hydrogen peroxide and peracetic acid in inactivating Staphylococcus aureus cells adhered onto these surfaces; and to visualize biofilm development by scanning electron microscopy before and after sanitizer treatment. The surfaces studied consisted of $10 \times 20 \mathrm{~mm}$ chips immersed in Petri dishes containing BHI broth inoculated with S. aureus ATCC 25923. Biofilm formation was observed after 15-day incubation, when the cells were removed using the swab technique, followed by Baird Parker agar plating. Also, the efficiency of the chemical sanitizers on the chip surfaces was tested and the non-removed cells were counted on the Baird-Parker agar. After biofilm formation and use of sanitizers, the chips were respectively observed by scanning electronic microscopy following a pre-existing protocol. The obtained results showed biofilm formation on both surfaces, with bacterial count in the order of $10^{7} \mathrm{CFU} / \mathrm{cm}^{2}$ on and $10^{8} \mathrm{CFU} / \mathrm{cm}^{2}$ on stainless steel and glass surfaces, respectively. Peracetic acid was the most efficient in removing adhered cells, presenting 5.26 and 4.5 decimal reduction for adhered cells on stainless steel and glass surfaces, respectively.
\end{abstract}

Key words: Biofilm, stainless steel, glass, Staphylococcus aureus, sanitizers, scanning electron microscopy.

\section{INTRODUCTION}

Both microbial adhesion and biofilms are of great importance for the food industry and occur on a high variety of food contact surfaces.

Microbial adhesion occurs due to microorganism deposition and attachment onto surfaces, initiating a growth process. Cell multiplication gives rise to colonies and biofilm is established when the cellular mass is thick enough to aggregate nutrients, residues and other microorganisms. (20).

Biofilms are constituted by bacteria adhered onto surfaces, which, in turn, are surrounded by a matrix of organic polymers. They can be considered a deposit where microorganisms are highly adhered onto a surface by means of appendixes of either protein or polysaccharide nature, referred to as glycocalyx (4).
Such appendix protrudes externally either from the outer membrane of gram-negative cells or from the peptideoglycan of gram-negative ones. Under a hydrated state, it contains from $98 \%$ to $99 \%$ of water, thus protecting the cells against dehydration, since they can hold water in much higher amounts than their own mass, slowly utilizing it when needed $(5,10)$.

A considerable number of both spoilage and pathogenic microorganisms is able to participate at a higher or lower intensity in both adhesion processes and biofilm formation. Pseudomonas aeruginosa, Pseudomonas fragi, Micrococcus spp and Enterococcus faecium $(4,9,16)$, are some of the spoilage microorganisms while Listeria monocytogenes, Yersinia enterocolitica, Salmonella thyphimurium, Escherichia coli O157:H7, Staphylococcus aureus and Bacillus cereus $(9,12,13)$ belong to the pathogenic group.

*Corresponding Author. Mailing address: UFLA - Dep. de Ciência dos Alimentos - Caixa Postal 3037 cep $37200-000$ Lavras, MG - Brasil. Tel.: (35) 3829-1656 ou (35) 3829-1391. E-mail: simone.marques@posgrad.ufla.br 
These microorganisms participate in the adhesion process with variable intensity. Microorganisms detached from the biofilm layer can be an important source of contamination and damage food quality, causing products to become potential carriers of pathogenic organisms.

Stainless steel, glass, rubber, and polypropylene surfaces can be contaminated either by spoilage or pathogenic microorganisms that, under certain conditions, are deposited, adhered to, and interact with the surface, initiating cellular growth, and consequently leading to biofilm formation $(12,13,17,20)$.

Among the techniques used to detect biofilm formation, electron microscopy is better indicated to evaluate the microbial interaction in the biofilm matrix. This method preserves the associated structures maintained under hydrated and viable conditions. Scanning electron microscopy is considered the most adequate technique for evaluating the interaction of microorganisms in the biofilm matrix. Samples are fixed with the help of a chemical agent, such as glutaraldehyde, pararformaldehyde and osmium, or cryo-fixed through quick freezing, to avoid cell damage by ice crystals $(3,8,18,19)$.

Given the significant damages caused by biofilm to food industries in general, further research must be conducted to elucidate its formation and procedures to remove it and prevent it from building up on food contact surfaces.

\section{MATERIALS AND METHODS}

\section{Surfaces}

AISI 304 stainless steel and glass surface chips of 10x20mm were used to study biofilm formation. These surface chips were individually cleaned and sanitized with pure acetone, immersed in a neutral detergent for $1 \mathrm{hr}$, flushed with sterile distilled water, and dried and cleaned with alcohol $(70 \% \mathrm{v} / \mathrm{v})$. After this sanitation process, the chips were submitted to an additional washing with sterile water, dried for $2 \mathrm{~h}$ at $60^{\circ} \mathrm{C}$ and sterilized in an autoclave at $121^{\circ} \mathrm{C}$ for $15 \mathrm{~min}$., according to a modified technique by Rassoni and Gaylarde (14).

\section{Biofilm}

Staphylococcus aureus ATCC 25923 culture was used as inoculum, after a certain number of viable cells was obtained $\left(10^{5} \mathrm{UFC}\right)$ from a growth curve, which in turn was built up by the correlation of optical density and plate count.

Twenty stainless steel chips and twenty glass chips were immersed into a solution of $60 \mathrm{~mL}$ of BHI and $10 \mathrm{~mL}$ of the above referred inoculum, previously placed into Petri dishes. The dishes were incubated by stirring at $37^{\circ} \mathrm{C}$ for $72 \mathrm{hr}$ ( 3 days). The chips were then removed and washed with sterile saline phosphate buffer solution (PBS pH 7.4) to remove the nonadhered cells. Once again, the chips were immersed into a fresh medium containing the same amount of inoculum, and the process was repeated 4 times,completing a 15-day period, in order to achieve the desired biofilm establishment.

\section{Cell count by the swab technique}

After 15-day incubation, two chips were removed from each dish with sterile tongs and washed with PBS. The biofilm was scraped with sterile swabs, which were transferred to tubes containing $9 \mathrm{~mL}$ of $0.1 \%(\mathrm{p} / \mathrm{v})$ peptone water solution, and Vortex shaken for $2 \mathrm{~min}$. Aliquots were transferred to Baird Parker agar, using the micro drop technique and incubated for $24 \mathrm{hr}$ at $37^{\circ} \mathrm{C}$ and viable cell count was performed.

\section{Scanning electron microscopy (SEM) analysis}

After 15-days, two chips of each material were removed from the dishes, washed with PBS and immersed into a fixing solution (Karnovisk) at $\mathrm{pH} 7.2$, and kept for $24 \mathrm{~h}$; after that, they were washed three times for $10 \mathrm{~min}$. with sodium cacodylate buffer, and post-fixed with a solution of $1 \%$ osmium tetroxide for $1 \mathrm{~h}$ at room temperature. The chips were washed three times with distilled water and dehydrated in a gradient series of acetone solutions $(25,50,75,90,100 \%)$. The material reached its critical point using $\mathrm{CO}_{2}$ as the transitional fluid (Baltec CPD 030). Chips were attached to specimen stubs with conductive silver paint and coated by vacuum evaporation, with a gold layer (Bal-tec SCD 050). Finally, the stainless steel and glass chips were examined by scanning electron microscopy (Evo40 Leo) (1).

Biofilms with a known number of viable cells were obtained to be used to verify the efficiency of the sanitizers tested.

\section{Sanitizer application}

Sanitizer efficiency in destroying cells in the biofilm matrix was studied using the sanitizers hydrogen peroxide, sodium dichloroisocyanurate and peracetic acid.

Solutions of $200 \mathrm{~mL}$ were prepared for each sanitizer, using the following concentrations: hydrogen peroxide, $5 \%$; sodium dichloroisocyanurate $100 \mathrm{mg} / \mathrm{L}$ and peracetic acid, $0.3 \%$. Two chips from each dish were washed with PBS, immersed in tubes containing $5 \mathrm{~mL}$ of the test solutions (sanitizers) for $30 \mathrm{sec}$, with the hydrogen peroxide at $30^{\circ} \mathrm{C}$ and the other two at room temperature. The chips were transferred into a neutralizing solution $\left(0.1 \mathrm{M} \mathrm{Na}_{2} \mathrm{~S}_{2} \mathrm{O}_{3}\right)$ and kept for 3 seconds. The remaining cells were counted after being swab-scraped and plated on a Baird Parker agar surface using the micro drop technique.

The efficiency of each sanitizer was calculated by the difference between the two observations (before and after sanitizer use)

\section{Scanning electron microscopy (SEM) analysis}

After the sanitizing process, two chips of each material were submitted to the same protocol as previously described for scanning electron microscopy observation of the remaining cells. 


\section{RESULTS AND DISCUSSION}

The results showing the adherence intensity of the $S$. aureus cells on both experimental surfaces, after 15-day incubation are shown in Fig. 1. The maximum number of viable cell adhesion was in the order of $10^{8} \mathrm{CFU} / \mathrm{cm}^{2}$ for the glass surfaces and $10^{7}$ for stainless steel surfaces, figures that, by their magnitude, clearly indicate biofilm formation on both surfaces.

The number of viable cells adhered onto the glass surfaces was statistically $(\mathrm{P} \leq 0.05)$ different from that found on stainless steel surfaces, the difference being in the order of one log cycle. The temperature $\left(37^{\circ} \mathrm{C}\right)$ used in the incubation process, which

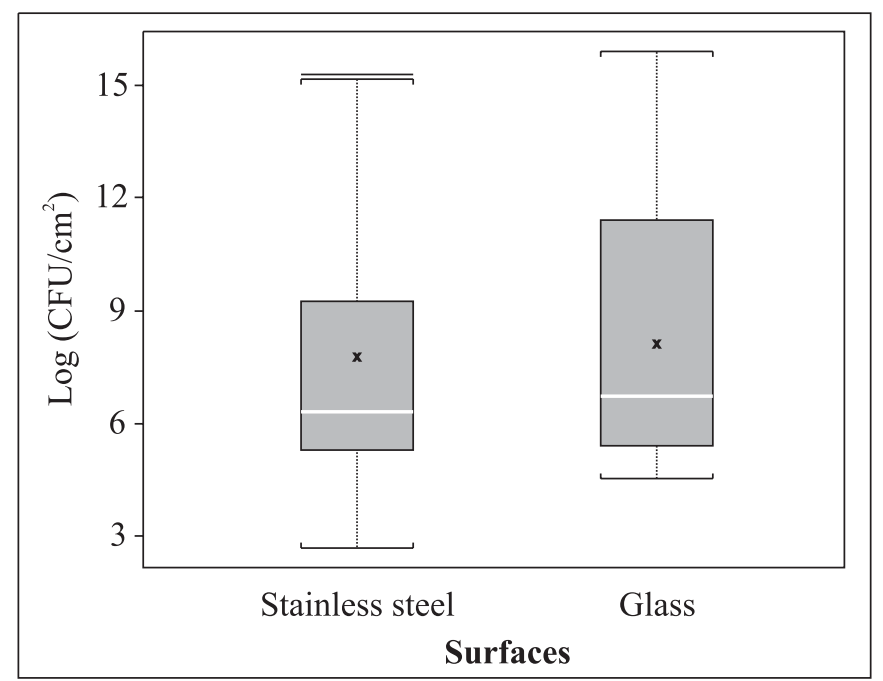

Figure 1. Mean of the log number of cells of Staphylococcus aureus ATCC 25923 adhered onto glass and stainless steel surfaces. is the ideal for S. aureus development, might have been one of the factors influencing the intense adhesion process on both surfaces Morton et al., (10) reported that, regardless of the species or surface utilized, the adhesion process occurs at maximum intensity when microorganisms are allowed to grow at their optimum temperature.

The intense adhesion observed on both surfaces may have occurred due the negative electrical charge of surface grampositive bacteria present when the medium is at neutral $\mathrm{pH}$, as it occurred in this work. BHI broth is a medium in which microbial metabolism can generate conditions that are fairly favorable to the adhesion process, affecting the surface charge characteristics, for instance. Mosteler and Bishop (11) reported that type of species and culture medium, as well as microorganism concentration, are factors that may also affect the adhesion process.

Zotolla and Sasahara (20) reported that for biofilm formation to occur, the number of adhesion cells must range from $10^{6}$ and $10^{7} \mathrm{CFU} / \mathrm{cm}^{2}$, and that values lower than those would be just an indication of an adhesion process.

As shown in Fig. 1, the glass surfaces presented a higher intensity of biofilm formation, compared to the stainless steel surfaces, with a difference in the order of one log cycle, which may be explained by the higher electric charge of the glass. The plate count of the swabs after being used to scrape the surfaces could indicate biofilm formation on both surfaces.

Scanning electronic microscopy (SEM) was used to observe both surfaces. Biofilm formation by $S$. aureus was clearly observed on both glass and stainless steel chip surfaces after a 15-day incubation period at $37^{\circ} \mathrm{C}$, as shown in Fig. 2 (A,B).

Scanning electronic microscopy allows the observation of bacteria/surface interaction and may be used as a semiquantitative technique. It is almost impossible to quantify surface microorganisms since they may be grouped and cells may be arranged in overlapped layers.
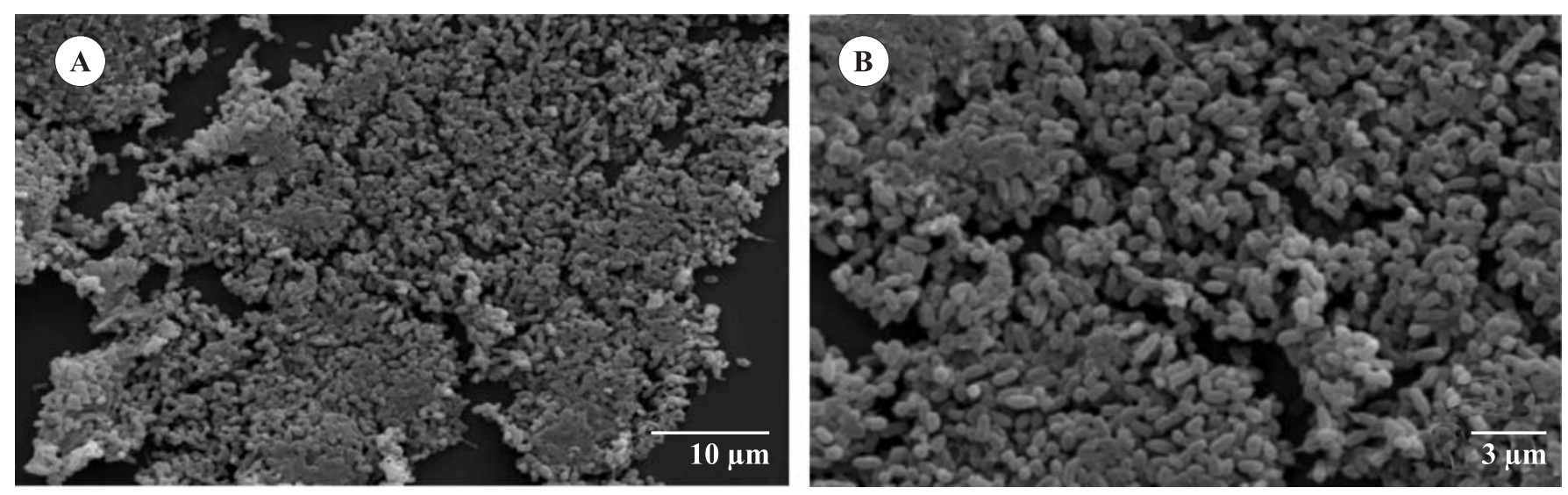

Figure 2. Electro micrographs of Staphylococcus aureus cells adhered onto glass (A) and stainless steel (B) surfaces, visualized by scanning electron microscopy. 
An important factor observed was the production of a considerable amount of exopolysaccharide matrix by $S$. aureus cells growing on the chip surfaces, as reported by Tsuneda et al., (15). The authors pointed out that adhesion of heterotrophic bacteria isolated from pearl glass from a water treatment reactor is inhibited by electrostatic interaction; this is of relevant importance since it alters the physical-chemical characteristics of the surface, such as charge, hydrophobicity and polymeric properties.

The electro micrographs obtained clearly indicate a fairly thick biofilm formation, which may be explained by the long contact between $S$. aureus culture and the chips, 15 days (360 hours).

According to research conducted by Gandara and Oliveira (6) stainless steel plates of $20 \mathrm{~cm}^{2}$ were incubated at $45^{\circ} \mathrm{C}$ with milk inoculated with about 1.0 $\mathrm{x} 10^{2} \mathrm{CFU} / \mathrm{cm}^{2}$ of an indigenous strain of Streptococcus thermophilus, under gentle stirring. After three hours of contact, the number of adhered cells was $1.6 \times 10^{1} \mathrm{CFU} / \mathrm{cm}^{2}$ and after six hours, $1.9 \mathrm{x}$ $10^{4} \mathrm{UFC} / \mathrm{cm}^{2}$. The authors suggest that the count would probably increase, becoming a biofilm if longer contact time had been used.

The literature on $S$. aureus biofilm formation on stainless steel and glass surfaces is quite scarce, making it difficult to conduct a comparative discussion of the results obtained. An important research work was conducted by Joseph et al. (7).The results presented in Fig. 1 are similar to those reported by these authors, who studied two Salmonella cultures isolated from chicken, (Salmonella weltevreden and Salmonella FCM40,) and found a population density of $10^{6}$ $\mathrm{CFU} / \mathrm{cm}^{2}$ for both cultures after a $48 \mathrm{hr}$ contact with stainless steel surface.

Counts of S. aureus cells adhered onto glass and stainless steel surfaces before and after using sodium dichloroisocyanurate hydrogen peroxide, and peracetic acid, are presented in Tables 1 and 2 .

When comparing the three sanitizers, peracetic acid was found to be the most effective in removing biofilm formed by $S$. aureus cells on both stainless steel and glass surfaces.

Variance analysis results showed a significant difference $(\mathrm{P}<0.05)$ among the three sanitizers used in the formation biofilm on the $S$. aureus cells adhered onto both stainless steel and glass surfaces, as shown in Fig. 3 and 4.

The electro micrographics of both stainless steel and glass coupons after application of the three sanitizers can be seen in Fig. 5.

The high efficiency of peracetic acid observed may be explained by its high capacity of oxidizing cell molecules. Such an action makes it a good sanitizer since it stays in equilibrium between the hydrogen peroxide and the acetic acid. Hydrogen

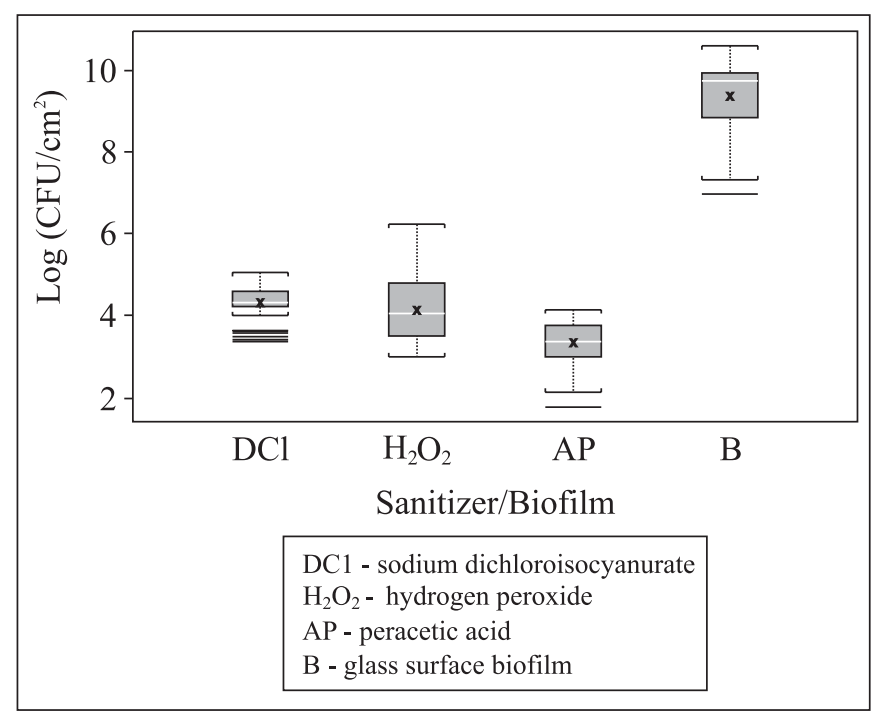

Figure 3. Mean of log number Staphylococcus aureus cells adhered onto glass surface, after and before use of sanitizer solutions of sodium dichloroisocyanurate, peroxide hydrogen and peracetic acid.

peroxide concentration in equilibrium is of great importance since its action is a result of an oxidative process upon the cell molecules. 


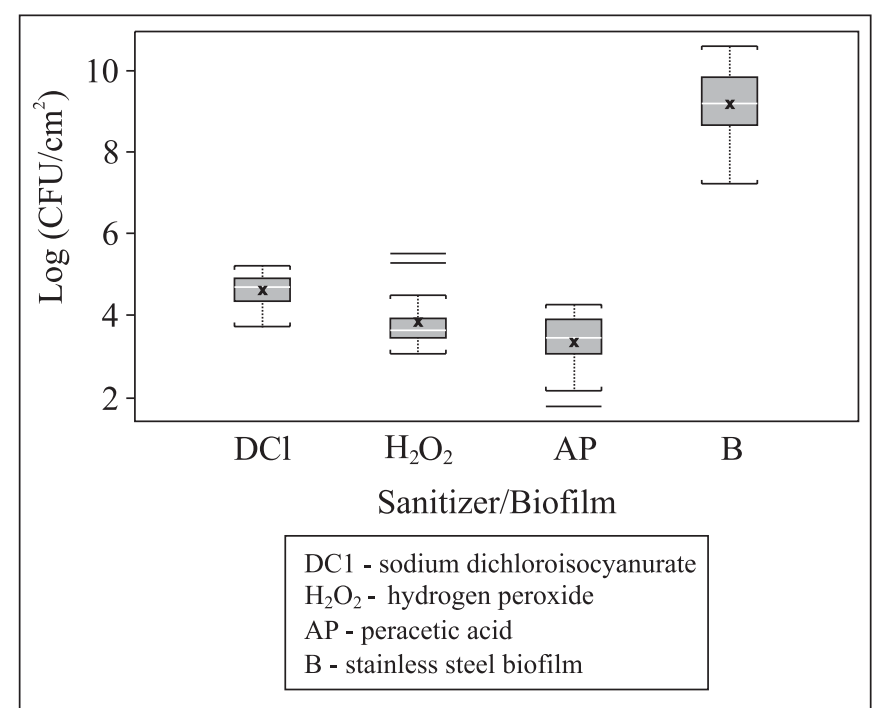

Figure 4. Mean of log number Staphylococcus aureus cells adhered onto stainless steel surface, after and before use of sanitizer solutions with sodium dichloroisocyanurate, peroxide hydrogen and peracetic acid.

Product labels do not specify the exact active compound concentrations; the manufacturers only state that the product contains between $390 \mathrm{mg} / \mathrm{L}$ and $540 \mathrm{mg} / \mathrm{L}$ of peracetic acid, as concentrations recommended by food industries, ranging between 300 and $700 \mathrm{mg} / \mathrm{L}$, according to Andrade and Macedo (2).

It must be emphasized that an appropriate and efficient hygienization process is of fundamental importance, since the American Public Health Association (APHA) recommends a maximum tolerated limit of $2 \mathrm{CFU} / \mathrm{cm}^{2}$ in order to consider a food contact surface appropriate, whereas the World Health Organization (WHO) suggests such limits as being $30 \mathrm{CFU} /$ $\mathrm{cm}^{2}$. Based on the results obtained and considerations included in this work, it can be stated that sodium dichloroisocyanurate hydrogen peroxide and peracetic acid, under the conditions used in this study, were not efficient in completely removing the cells of $S$. aureus, adhered onto glass and stainless steel surfaces.

\section{RESUMO}

\section{Formação de biofilme por Staphylococcus aureus na superfície de aço inoxidável e vidro e sua resistência a alguns sanificantes químicos}

Os objetivos deste trabalho foram verificar a capacidade de Staphylococcus aureus formar biofilme nas superfícies de aço inoxidável e vidro, avaliar a eficiência do dicloroisocianurato de
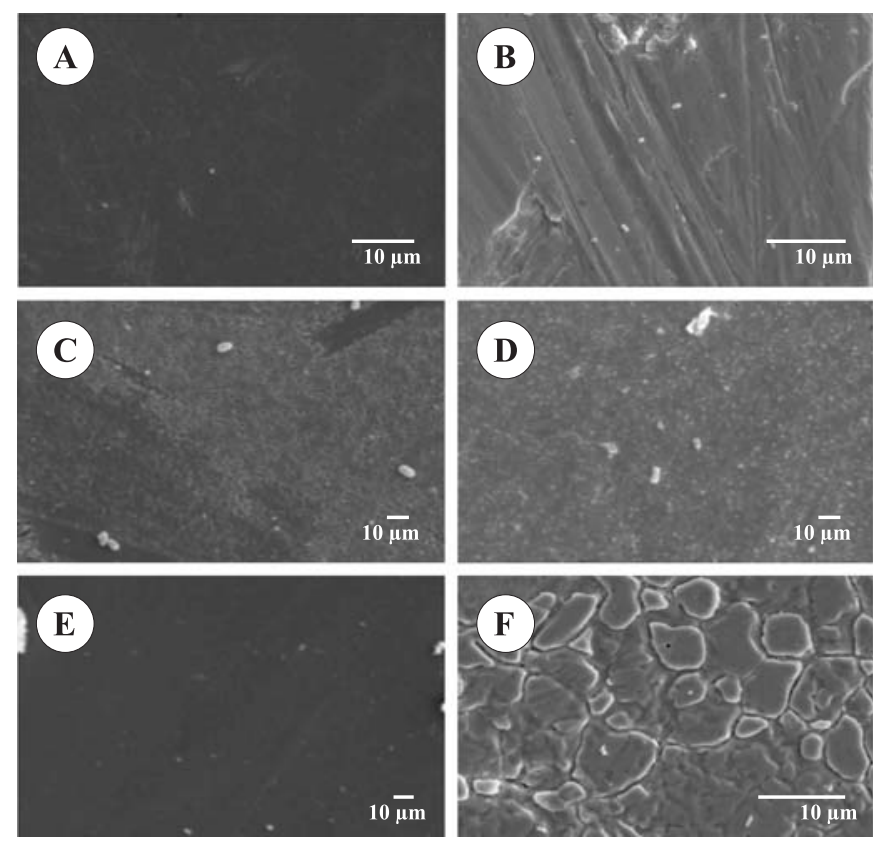

Figure 5. Electro micrographs of Staphylococcus aureus cells adhered onto glass and stainless steel surfaces, after the use of sanitizer solutions with sodium dichloroisocyanurate (A, B), peroxide hydrogen $(C, D)$ and peracetic acid (E, F).

sódio, peróxido de hidrogênio e ácido peracético na inativação de células de $S$. aureus aderidas e visualização por microscopia eletrônica de varredura, o desenvolvimento antes e depois do tratamento das superfícies com os sanificantes. As superfícies foram cupons 10x200mm imersos em placas de Petri contendo caldo BHI inoculado com cultura de Staphylococcus aureus ATCC 25923. A formação de biofilme foi observada após 15 dias de incubação, quando as células foram removidas pela técnica do suabe, seguiram-se diluições seriadas e plaqueamento em ágar Baird Parker. Testou-se a eficiência dos sanificantes nas superfícies dos cupons e as células não removidas foram enumeradas no ágar Baird Parker. Os cupons após formação do biofilme e cupons sanificados foram observados pela microscopia eletrônica de varredura seguindo um protocolo. Os resultados obtidos indicaram a formação de biofilme em ambas superfícies, com contagens bacterianas na ordem de $10^{7}$ $\mathrm{UFC} / \mathrm{cm}^{2}$ e $10^{8} \mathrm{UFC} / \mathrm{cm}^{2}$ nas superfícies de aço inoxidável e vidro, respectivamente. Dentre os sanificantes estudados o ácido peracético apresentou uma eficiência maior na remoção das células aderidas, apresentado redução decimal de 5,26 e 4,5 para as células aderidas na superfície de vidro e aço inoxidável.

Palavras-chave: Biofilme, aço inoxidável, vidro, Staphylococcus aureus sanificantes, microscopia eletrônica de varredura. 


\section{REFERENCES}

1. Alves, E. (2004). Introdução a Microscopia Eletrônica de Varredura Laboratório de Microscopia Eletrônica e Análise Ultra-estrutural. 43 p.

2. Andrade, N.J.; Macêdo, J.A.B. (1996). Higienização na indústria de Alimentos. São Paulo: Livraria Varela, 180 p.

3. Costa, E.T.R. (1999). Desenvolvimento de metodologia para detecção da adesão microbiana em superfície de aço inoxidável. 81p. Dissertação (Mestrado em Microbiologia Veterinária) Universidade Federal Rural do Rio de Janeiro, Seropédica.

4. Criado, M.T.; Suarez, B.; Ferreros, C.M. (1994) .The importance of bacterial adhesion in dairy industry. Food Technol., Chicago, 48(2), 123-126.

5. Figueiredo, H.M. (2000). Adesão bacteriana em modelo de circuito de processamento de leite. Viçosa, Brasil, 76p. (PhD Thesis. Food Science and Technology, UFV).

6. Gândara, A.L.N.; Oliveira, J.S. (2000). Adesão de linhagem selvagem de Streptococcus thermophilus em superfície de aço inoxidável e efeitos da higienização na sua remoção. Ciênc. Tecnol. Alim., 20(1), 1-7.

7. Joseph, B.; Ottas, S.K.; Karunasagar, I. (2001). Biofilm formation by Salmonella spp.On food contact surfaces and their sensitivity to sanitizers. Intern. J. Food Microbiol., 64(3), 364-367.

8. Kumar, C.G.; Anand, S.K. (1998). Significance of microbial biofilms in food industry: a review. Int. J. Food Microbiol., 42(1/2), 9-27.

9. Leriche, V.; Carpentier, B. (1995). Viable but noncultural Salmonella typhymurium in single and binary biofilms in response to chlorine treatment. J. Food Prot., 58(11), 1186-1191.

10. Morton, L.H.G.; Greenway, D.L.A.; Gaylarde, C.C.; Surman, S.B. (1998) Consideration of some implications of the resistance of biofilms to biocides. Int. Biodeterior. Biodegradation, 41(3/4), 247-259.

11. Mosteller, T.M.; Bishop, J.R. (1993). Sanitizer efficacy against attached bacteria in a milk biofilm. J. Food Prot., 56(1), 34-41.
12. Parizzi, S.Q.F. (1999). Adesão bacteriana em diferentes superfícies avaliada pela Microscopia de Epifluorescência e Contagem em Placas. Viçosa, Brasil, 58p. (M.Sc. Dissertation. Ciência e Tecnologia de Alimentos, UFV).

13. Pompermayer, D.M.C.; Gaylarde, C.C. (2000). The influence of temperature on the adhesion of mixed cultures of Staphylococcus aureus and Escherichia coli to polypropylene. Food Microbiol., 17(4), 361-365

14. Rassoni, E.M.M.; Gaylarde, C. (2000). Comparison of sodium hypochlorite and peracetic acid as sanitizing agents for stainless steel food processing surfaces using epifluorescence microscopy. Int. J. Food Microbiol., 61(1), 81-85.

15. Tsuneda, S.; Aikawa, H.; Hayashi, H.; Yuasa, A.; Hirata, A. (2003) Extracelullar polymeric substances responsible for bacterial adhesion onto solid surface. FEMS Microbiol. Lett., 223(2), 287-292.

16. Wirtanen, G.; Helander, I.M.; Matilla-Sandholm, T. (2000). Microbial methods for testing disinfectant efficiency on Pseudomonas biofilm. Colloids Surf B Biointerfaces, 20(1), 37-50.

17. Zacheus, O.M.; Ivanainen, E.K.; Nissinen, T.K.; Lehtola, M.J.; Martikainen, P.J. (2000). Bacterial biofilm formation on polyvinyl chloride, polyethylene and stainless steel exposed to ozonated water. Water Res., 34(1), 63-70.

18. Zoltai, P.T.; Zottola, E.A.; Mckay, L.L. (1981). Scanning electron microscopy of microbial attachment to milk contact surfaces. $J$. Food Prot., 44(3), 204-208.

19. Zottola, E.A. Tortorello, M.L.; Gendel, S.M. (1997). Special techniques for studying microbial biofilms in food system. In: TORTORELLO, M. L.; GENDEL, S. M. (Ed.) Food microbial analysis: new technologies. IFT basic symposium series. New York: Marcell Dekker, Cap. 16, p.315-346.

20. Zottola, E.A.; Sasahara, K.C. (1994). Microbial biofilms in the food processing industry-Should they be a concern? Int. J. Food Microbiol., 23(2), 125-148 